This item was submitted to Loughborough's Research Repository by the author.

Items in Figshare are protected by copyright, with all rights reserved, unless otherwise indicated.

\title{
Antecedents of adaptive selling among retail salespeople: a multilevel analysis
}

PLEASE CITE THE PUBLISHED VERSION

http://dx.doi.org/10.1016/j.jretconser.2013.04.004

PUBLISHER

(C) Elsevier

VERSION

AM (Accepted Manuscript)

\section{PUBLISHER STATEMENT}

This work is made available according to the conditions of the Creative Commons Attribution-NonCommercialNoDerivatives 4.0 International (CC BY-NC-ND 4.0) licence. Full details of this licence are available at: https://creativecommons.org/licenses/by-nc-nd/4.0/

\section{LICENCE}

CC BY-NC-ND 4.0

\section{REPOSITORY RECORD}

Simintiras, Antonis, Kemefasu Ifie, Alan Watkins, and Konstantinos Georgakas. 2019. "Antecedents of Adaptive Selling Among Retail Salespeople: A Multilevel Analysis". figshare.

https://hdl.handle.net/2134/19107. 


\title{
Antecedents of Adaptive Selling among Retail Salespeople: A Multilevel Analysis
}

\author{
Antonis Simintiras \\ Kemefasu Ifie* \\ Alan Watkins \\ Konstantinos Georgakas
}

* Corresponding Author

Antonis C Simintiras,

School of Business and Economics, Swansea University, Singleton Park Swansea SA2 8PP, Wales, United Kingdom;

Tel: $+44(0) 1792295740$

Fax: ++44(0)1792295626

Email: a.c.simintiras@swansea.ac.uk

Alan Watkins

School of Business and Economics, Swansea University, Singleton Park Swansea SA2 8PP, Wales, United Kingdom;

Tel: +44(0)1792295853

Fax: ++44(0)1792295626

Email: a.watkins@swansea.ac.uk
Kemefasu Ifie,

School of Business and Economics, Swansea University, Singleton Park Swansea SA2 8PP, Wales, United Kingdom; Tel: +44(0)1792295397 Fax: ++44(0)1792295626

Email: k.ifie@swansea.ac.uk

Konstantinos Georgakas

Gecon Consulting, 8 Kofidou Str., Panorama, 55236, Thessaloniki, Greece Tel: +30 2310344091 -

Fax: +30 2310344046

Email: info@gecon.gr 


\title{
Antecedents of Adaptive Selling among Retail Salespeople: A Multilevel Analysis
}

\begin{abstract}
The literature on adaptive selling behavior has grown rapidly over the years, with heavier emphasis placed on industrial/professional salespeople and less attention given to retail salespeople. This study contributes to addressing this imbalance by examining the effects of two salesperson factors (selling skills and affective commitment) and two company-level variables (empowerment and behavior-based control) on the adaptive selling behavior of retail salespeople. Using data obtained from a two staged sampling procedure (105 companies and 419 salespeople), we employ a multilevel analytical procedure to model the effects of the salesperson and organizational factors on adaptive selling behavior of retail salespeople. The results indicate that selling skills and affective commitment directly influence adaptive selling while empowerment and behavior based control only indirectly influence adaptive selling behavior. Based on the findings of this study, implications for managing retail salespeople as well as limitations and suggestions for future research are presented.
\end{abstract}

Keywords: Affective commitment, selling skills, adaptive selling, empowerment, behavior-based control, multilevel modeling. 


\section{Antecedents of Adaptive Selling among Retail Salespeople: A Multilevel Analysis}

\section{Introduction}

Salespeople are typically aware of the existence of different types of customers (Sharma and Levy, 1995) and the need for using different selling approaches for successful selling (Plouffe, Hulland and Wachner, 2009). The practice of using different selling approaches to meet customer needs is known as adaptive selling behavior (ASB). There is general consensus that adaptive selling behavior is desirable. One primary benefit of ASB is that it results in improved sales performance (Román and Iacobucci, 2010). Consequently, significant research effort has been devoted to identifying factors that influence the practice of ASB (Román and Iacobucci, 2010; Giacobbe, Jackson, Crosby and Bridges, 2006). These factors include role conflict, sales experience (Levy and Sharma, 1994; Siguaw, 1993), empathy, locus of control, management (Spiro and Weitz, 1990), intrinsic reward orientation, psychological androgyny (Goolsby, Lagace and Boorom, 1992), learning orientations, job satisfaction (Park and Holloway, 2003), pride, self-efficacy and civic virtue (Verbeke, Belschak and Bagozzi, 2004).

Despite the significant research attention that has revolved around the antecedents of ASB, an examination of the literature reveals that very little research has focused on adaptive selling behavior in a retail sales environment. Only a handful of studies (e.g. Levy and Sharma, 1994; Sharma, 2001; Mallalieu, 2006) have explicitly addressed the antecedents and consequences of adaptive selling among retail salespeople. 
Two reasons may partly account for this lack of adaptive selling research in retail sales. First, scholars may assume, given the self-selection/self-service nature of much of retailing, that the practice of adaptive selling is not as important in a retail sales setting as it is in industrial selling. However, there are reasons why the practice of adaptive selling is equally important in many retail sales contexts (Sharma, 2001). For instance, whilst the industrial salesperson typically deals with a more formula-driven buyer (Barry and Weinstein, 2009), a key aspect of the salesperson's role in many retail sales environments such as jewelry, opticians etc. is to persuade customers who are often not entirely certain of what they want (Sharma, 2001; Goff, Bellenger and Stojack, 1994). Furthermore, due to hyper-competition in the retail sector, there is an increasing need for salespeople to work smart in terms of their selling in order to gain and keep customers (Sharma, 2001).

A second possible reason for the paucity of research activity on adaptive selling in retail sales may be the assumption that the findings that pertain to industrial or professional salespeople would apply in a retail setting. However, the work environment and conditions, under which retail salespeople work, are significantly different from those of industrial salespeople. One important difference is that the sales manager is likely to be present in the retail environment unlike in the industrial sales context. This fundamental difference means that the influence of certain structural and managerial factors (e.g. the effects of empowerment and salesforce controls on adaptive selling) may be different for retail salespeople than for industrial salespeople. Retail salespeople are also more likely to be salaried rather than commission-based employees. As such, motivations for engaging in adaptive selling might be different among retail salespeople than industrial or professional salespeople. 
The issues discussed above suggest the need for research to ascertain the factors that influence adaptive selling among retail salespople. Such research can also confirm whether antecedents identified in industrial sales contexts apply to retail salespeople. Accordingly, the purpose of this study is to investigate the influence of two salesperson-specific factors (selling skills and organizational affective commitment) and two firm-level factors (empowerment and behaviorbased control) on salespeople’s ASB.

The rationale for investigating these antecedent variables is as follows. First, a review of the literature indicates that factors specific to the organizational environment such as salesforce control systems and empowerment are likely to impact on adaptive selling. However, while the role of salesforce control systems for the practice of ASB has received a lot of research attention, there have been inconsistencies in findings of past studies (Evans, Landry and Zou, 2007; Fang, Evans and Zou, 2005). Given the importance of adaptive selling for successful sales outcomes and the fact that salesforce control systems constitute the most important management tool in sales management (Anderson and Oliver, 1987), further investigations into the extent to which (and through what mechanisms) salesforce control systems affect the ASB of salespeople is necessary. Furthermore, given that the retail sales environment is different from the field sales environment, it is important to examine whether and how control systems influence adaptive selling among retail salespeople.

Second, we aim to be robust by examining constructs that reflect the three principal domains found to be determinants of salespersons’ performance. As such, the salesperson-related factors 
examined in this study, that is, organizational affective commitment and selling skills are two theoretically important variables that relate to two of these principal domains: (i) salespersons' motivations and attitudes, and (ii) salespersons’ skills (cf. Churchill et. al., 1985). Furthermore, the firm-level variables we investigate directly relate to the third domain: salesperson role perceptions (Cravens, Lassk, Low, Marshall and Moncrief , 2004). Thirdly, by investigating both salesperson and firm variables in our study, we adhere to suggestions in the literature that factors specific to salespeople should be examined and modeled in the context of a firm's characteristics (Román and Iacobucci, 2010).

This study contributes to sales management research in two important ways. First, by focusing on both salesperson-related and managerial practices, this study provides an in-depth investigation of antecedents of adaptive selling among retail salespeople. Whilst some relationships in this study, such as the influence of selling skills, are documented in the literature, we specifically investigate them in a retail sales environment. However, and more importantly, some of the relationships in this study have not been addressed in previous studies. For example, we could not find any studies explicitly documenting the relationship between affective commitment and adaptive selling or the moderating effect of behavior-based control on the influence of selling skills. In essence, while there are studies to support some parts of our conceptual model individually, our proposed nomological network, as a whole, requires empirical validation. We therefore contribute to the literature by testing these additional hypotheses, thereby offering new insights both to organizations and researchers. The second contribution of this study is the methodology we apply to investigate antecedents of ASB. Specifically, we collect information about organizational constructs from managers and 
information about salesperson constructs from salespeople in a variety of retail sales organizations and analyze them using a multilevel modeling approach. Research suggests that studies focusing on salespersons' perceptions of their own constructs, in addition to their perceptions of their organization, are likely to be somewhat more biased and intrinsically less holistic than studies such as ours where data is obtained from multiple sources (Román and Iacobucci, 2010). Our analytical approach also appropriately models the multilevel nature of retail sales organizations, thereby providing more robust results pertaining to the antecedents of adaptive selling.

The remainder of this paper is structured as follows: in the literature review and hypothesis section, we discuss the literature pertaining to ASB and all influencing factors of interest in this study, and then present the research hypotheses. The methodology section explains and describes the analytical approach used. Next, we explain the modeling procedure adopted and provide the results of this study. This is followed by the discussion and conclusion section where theoretical and managerial implications are presented, the study's limitations highlighted and areas for further research suggested.

\section{Literature Review and Hypotheses}

\subsection{Adaptive Selling Behavior}

The practice of adaptive selling is defined as the altering of sales behaviors during a customer interaction or across customer interactions based on perceived information about the nature of the selling situation (Weitz et al., 1986; Gengler, Howard and Zolner, 1995; Weitz Sujan and 
Sujan, 1986). Inherent in this definition is the notion that ASB is a complex process that emphasises customised sales solutions tailored to an individual customer (Cannon and Perreault, 1999).

The adaptive selling process consists of gathering information about prospective customers, developing sales strategies based on this information, transmitting messages to implement those strategies, evaluating the impact of these messages, and making adjustments based on these evaluations (Weitz, 1978; Pettijohn et al., 2000). Eckert (2006) explains the process using a three-stage model. The first stage involves the inputs to a selling interaction that form the characteristics of that selling situation; the second stage involves the behaviors undertaken to process and understand those inputs; and the third stage involves the range of outputs possible as an adaptive response to the situation created by the inputs. The degree of engagement in process corresponds to different levels of adaptiveness ranging from advanced to intermediate to elementary order adaptiveness (Porter et al., 2003). Consequently, salespeople exhibit high levels of ASB when they use different sales presentations across sales encounters and when they make adjustments during these encounters. In contrast, the use of the same sales presentation in and during all sales encounters indicates low levels of ASB (Spiro and Weitz, 1990).

Nowadays, with heavy emphasis being placed on the role of retail salespeople in ensuring that consumer needs are met, retail salespeople need to understand consumer decision-making and must be able to quickly identify consumer needs and respond with an appropriate selling behavior (Sharma, 2001; Mallalieu, 2006). Given the fact that research findings indicate that ASB improves salesperson performance regardless of the circumstances (e.g. Franke and Park, 
2006; Boorom et al., 1998; Spiro and Weitz, 1990; Sujan et al., 1994), a critical question is how various person-specific and organizational factors influence the ASB of retail salespeople. In the following sub-sections, we discuss the antecedent factors before providing hypotheses linking them to retail salespeople's ASB. Figure 1 provides the conceptual framework detailing the relationships among the focal constructs and the hypotheses which we propose in this study.

\section{Insert Figure 1 here}

\subsection{Empowerment and Adaptive Selling}

There are two conceptions of empowerment: (i) relational/organizational, and (ii) motivational (Conger and Kanungo, 1988; Ahearne et al., 2005). The former conception defines empowerment as a practice, or set of practices involving the delegation of responsibility down the hierarchy so as to give employees increased decision-making authority with respect to the execution of their primary work tasks (Leach et al., 2003:28). The second conception considers empowerment as increased task motivation manifested in four cognitions: meaning, competence, self-determination, and impact (Thomas and Velthouse, 1990).

This study focuses on the practice of empowerment because sales managers are the ones who ultimately decide upon salespeople’s empowerment. Empowering salespeople involves expressing belief and confidence in salespeople, implementing conditions that increase their

feelings of self-efficacy and control, establishing realistic but high-performance expectations for them, removing conditions that foster a sense of powerlessness, and allowing them the freedom to be flexible as circumstances warrant (Burke, 1986; Arnold, Arad, Rhoades and Drasgow, 
2000). It is through empowerment that salespeople can feel motivated and sufficiently confident to assume control over decision-making in their work (Anderson and Huang, 2006). Through this motivational impact, empowerment should enhance salespeople’s likelihood of using adaptive selling techniques (Rapp, Ahearne, Mathieu and Schillewaert 2006). Furthermore, the increased flexibility afforded by empowerment means that more empowered salespeople, in comparison to less-empowered ones, are more able to adapt their selling strategies instantaneously as circumstances warrant (Scott and Bruce, 1994). In essence, therefore, the more salespeople are encouraged to generate and practice their ideas, the more likely it is that their practice of ASB will increase. Consequently, we propose the following hypothesis:

$\mathrm{H}_{1}$ : Empowerment has a positive influence on salespersons’ ASB.

\subsection{Behavior-Based Control and Adaptive Selling}

Control systems are an aggregate of policies, procedures, and rules that marketing organizations use to monitor, direct, evaluate, and reward employees (Anderson and Oliver, 1987). Control systems have been classified into two types: those that emphasise end results (i.e. outcome control) and those that stress inputs and processes (i.e. behavior control). Behaviorbased control systems rely more on sales manager monitoring, directing, evaluating, and rewarding salespeople whereas outcome-based control systems are predominantly based on measuring salesperson outcomes (Anderson and Oliver, 1987). Behavior-based control systems are thus characterised by high levels of direction and the close monitoring of activities that management considers important in achieving desired (tangible and intangible) results (Anderson 
and Oliver, 1987), and are by far the most commonly utilised systems for evaluating retail salespeople (Malin and Pullins, 2009).

Research findings concerning the direct effects of sales control systems on job-related outcomes have been inconsistent (Challagalla and Shervani, 1996; Fang et al., 2005). More specifically, research has shown that behavior control has a positive impact on job performance (e.g. Babakus, Cravens, Grant, Ingram and LaForge, 1996; Piercy et al., 1998; Oliver and Anderson, 1994), a negative impact (e.g. Jaworski and McInnis, 1989; Ramaswami, 1996), and no direct relationship (e.g. Challagalla and Shervani, 1996; Lusch and Jaworski, 1991). Challagalla and Shervani (1996) conclude that both outcome control and behavior control have little direct effect on sales performance. They suggest that the inability to consistently find effects of salesforce control on end-outcomes, such as performance and satisfaction, may lead to inappropriate conclusions about the efficacy of control systems.

However, most of the research addressing the effects of salesforce control systems on sales performance has been conducted in the industrial setting. We suggest that the direct effect of a behavior-based control system on adaptive selling may be more evident in a retail sales environment than in an industrial sales environment. Monitoring the behavior of field sales employees is difficult because the manager is not present and thus behavior-based controls might not be effective in influencing the behavior of field salespeople. In the retail setting, however, the sales manager's constant presence means that salespeople can be more closely monitored, thereby potentially influencing their practice of adaptive selling. 
In this paper, we suggest, contrary to what most studies argue, that the influence of behaviorbased control on ASB is negative rather than positive. Salespeople's perception of support differs from a perception of being closely monitored. Under a behavior-based control system, salespeople are appraised according to how well they follow the directions of the firm (Anderson and Oliver, 1987). This creates incentives for salespeople to follow what they believe to be the firm’s directives rather than improvise - which is a key part of adaptive selling. Moreover, because their actions are under greater scrutiny, they have less opportunity and freedom to practice adaptive selling. Finally, a negative relationship results from the implicit signal that monitoring sends; which is that salespople cannot be trusted (Arnold et al., 2009). Therefore, though these systems are generally created with good intentions, behavior-based control forces the retail salesperson into a prescribed set of actions that are likely to discourage them from experimenting with and implementing different selling approaches. Consequently, we advance the following hypothesis:

$\mathrm{H}_{2}$ : Behavior-based control has a negative influence on ASB.

\subsection{Affective Organizational Commitment and Adaptive Selling}

Organizational commitment is defined in the literature as consisting of three dimensions; affective, continuance, and normative (Meyer and Allen, 1997). The affective commitment dimension is the most extensively researched in terms of its antecedents and consequences (Sturges et al., 2001) and is considered a more effective measure of organizational commitment than the other two dimensions as it shows stronger effects on employee outcomes (Meyer et al., 2002). Affective commitment is the relative strength of an employee's identification with and 
involvement in a particular organization (Mowday et al., 1979). Research indicates that salespeople with higher levels of affective commitment to their work, their job, and their career exhibit higher levels of continuance and normative commitments (Cohen, 1996). Although all dimensions of organizational commitment are important, this study focuses on affective commitment as it appears to directly influence effort as well as indirectly influence the other two dimensions of organizational commitment.

The impact of overall organizational commitment on salespersons' behavior has attracted the attention of many scholars (e.g. Hunt et al., 1985; Chonko, 1986; Michaels et al., 1988; Ingram et al., 1989; Johnston et al., 1990; Brown and Peterson, 1993; Singh et al., 1996). Their general findings suggest that committed salespeople give more adequately of their time, energy, talent, judgment, ideas, and moral courage in the best interests of the company (Stewart, 1961). In contrast, less committed salespeople are difficult to motivate, are only in their jobs for the money, do not follow-up customers and do not care about their jobs, departments, or customers (Still, 1983). Affective commitment has also been associated with valuable organizational outcomes, such as a higher level of effort, and a stronger desire to remain in the organization $(\mathrm{Fu}$, Bolander and Jones, 2009). Moreover, in a retail context, Zeithaml, Parasuraman and Berry (1990) suggest that committed salespeople have the urge to engage in discretionary efforts leading to customer satisfaction and retention. Adaptive selling in a retail sales environment requires such discretionary effort on the part of the salesperson. Since retail salespeople are rarely commission-based employees, the motivation for engaging in adaptive selling is likely to arise from positive feelings towards the organization rather than from a desire to maximize 
personal benefits. Therefore, affective commitment should have a positive impact on the practice of ASB. Consequently, the following hypothesis is suggested:

$\mathrm{H}_{3}$ : Affective commitment has a positive influence on ASB.

\subsection{Selling Skills and Adaptive Selling}

Selling skills are fundamental to the success of sales interactions and are considered a critical determinant of sales effectiveness (Walker et al., 1977). In a meta-analytic study by Churchill, Ford, Hartley and Walker (1985), selling skills emerged as the strongest single determinant of salesperson performance. Selling skills primarily embrace competencies that relate to the interactions of salespeople with customers. Traditionally, selling skills have been measured by concepts such as technical knowledge, sales comprehension, sales style, empathy, and ability to resolve conflicts (Churchill, Ford and Walker, 1997). Rentz et al. (2002), developed a scale incorporating three sub-dimensions of selling skills: interpersonal skills (e.g. verbal and nonverbal communication proficiency); salesmanship skills (e.g. sales presentation competencies); and technical skills (e.g. the salesperson's knowledge of the technical capabilities and features of his/her products and product portfolio).

Salespeople’s selling skills influence their ability to adapt their selling strategy during a sales interaction (Weitz et al., 1986). The influence of selling skills on ASB is exerted through the knowledge that salespeople use to evaluate sales situations and develop sales strategies for each customer (Weitz et al., 1986; Sharma et al., 2000). Recent studies provide support for this link between selling skills and performance. For example, Rentz et al. (2002) reported a significant 
positive correlation between dimensions of selling skills and two self-reported measures of performance. Similarly, research by Plouffe et al. (2009) indicates that selling skills is a significant predictor of salespeople’s performance. Wachner, Plouffe and Gregoire, (2009) as well as Pettijohn, Pettijohn and Taylor (2007) further confirm the main effect of selling skills on subjective performance. Consistent with these findings we propose that:

$\mathrm{H}_{4}$ : Selling skills have a positive influence on salespersons’ ASB.

2.6. Affective Commitment and Adaptive Selling: The Moderating Role of Empowerment

Affective commitment signifies a desire of an employee to be an active contributor to the success of his or her organization (Jaramillo et al., 2005). However, employees are more likely to contribute through adaptive selling when the environment affords them the opportunity to do so. Empowerment provides the salesperson with the opportunity to use their initiative to provide better outcomes for the organization by allowing them the freedom to be flexible as circumstances warrant (Arnold et al., 2000). It is expected that the affective commitment of salespeople will have a stronger effect on their ASB when empowerment is higher, and therefore we propose the following:

$\mathrm{H}_{5}$ : The influence of affective commitment on salespersons' ASB is stronger for higher levels of empowerment. 


\subsection{Selling Skills and Adaptive Selling: The Impact of Behavior Based Control}

Another question of interest is how an organization's control system interacts with salesperson's characteristics to influence sales performance. Prior research has examined salesforce control systems as moderators of the influence of salesperson variables on performance. For example, Ahearne, Rapp, Hughes and Jindal (2010) investigated the moderating effect of behavior-based (and outcome-based) controls on the relationship between salespersons' new product perception and effort directed into new products. However, the issue of interest in this study is whether the level of behavior-based control present in an organization enhances or diminishes the effect of salespersons' selling skills on adaptive selling. We expect that behavior-based control will weaken the positive effect of selling skills on the practice of ASB.

Behavior based-control reduces the freedom that salespeople have and thus constrains salespersons from utilising the full range of their skills. Consequently, the greater the use of behavior-based control, the more employees will feel the need to follow their organization's directives and thus will be less prone to adapting their selling behavior to meet customer needs. The result of this is that the positive effect that their selling skills should have on adaptive selling becomes weaker. In light of this, the following hypothesis is presented:

$\mathrm{H}_{6}$ : The influence of selling skills on ASB is stronger (weaker) for lower (higher) levels of behavior-based control. 


\section{Methodology}

\subsection{Data Collection}

We chose retail organizations in mainland Greece as the population for this study. A random two-stage sampling design was used in which a stratified random sample of primary entities (i.e. companies) was taken in the first stage. The secondary units (i.e. salespeople) were subsequently sampled at random from the selected companies in the second stage (Snijders and Bosker, 2004).

In total, a nationwide sample of 105 companies was randomly selected in the first stage; in the second stage 419 salespeople were randomly sampled from those companies. As a result, the total sample comprises responses from 419 retail salespeople and 105 retail sales managers or business owners. Each firm provided an average of four employee responses and one management response. A range of retail businesses (31 different types) are represented, the majority being independent clothes retailers (25.7\%) jewellery/accessory retailers (10.5\%), chain clothes retailers (9.5\%), shoe retailers (6.7\%), electrical products retailers (4.8\%), bookstores (4.8\%), house-ware products retailers (4.8\%), art retailers (3.8\%), opticians (2.9\%), and hightech products retailers (2.9\%). The remaining types of retailers are represented by one (1\%) or two (1.9\%). The majority of retailers were small and medium sized companies.

We collected data from sales managers by use of a questionnaire administered through faceto-face interviews and from salespeople using a self administered questionnaire. The questionnaires for salespeople were placed in envelopes and collected the next day by one of the authors. In an effort to minimise social desirability bias salespeople were told their responses 
would remain anonymous and would not been seen by their managers. Approximately 66\% of the sales managers were male and 34\% female with both groups averaging 37 years of age. $44 \%$ of the salespeople were male and 56\% female with both groups averaging 30 years of age. The average tenure of salespeople was 4 years but ranged between 3 months to 20 years. The variables used in the analysis are shown in Table 1.

Insert Table 1 here

\subsection{Measures}

The measurement of each variable was generated from established measurement scales. Appendix 1 lists the measures and their sources. The questionnaire was back translated and pretested. The wordings of some items were altered; all items in scales were retained, and for all scales Likert-type response categories (1 strongly agree - 7 strongly disagree) were used.

Scales were subjected to a reliability and convergent validity analyses; and the results are summarized by construct reliability (CR) and average variance extracted (AVE). The results are included in table 2. With the exception of behavior-based control where the AVE is below the recommended level of 0.5 , the other scales showed acceptable reliability and convergence validity. The scores of the five scales (i.e. EM, BC, AC, SS, and ASB) were summated and mean centered. Means standard deviations and correlations among the variables are also presented in Table 2 .

Insert Table 2 here 


\subsection{Modeling Approach}

To examine the effects of the antecedent variables on ASB, we performed multilevel analysis. Multilevel analysis provides the opportunity to model contextual effects, and should be used when a multi-stage sampling design is employed. The modeling approach used is a step-up approach. Specifically, the level-2 covariates were entered into the equation first, followed by the inclusion of the level-1 covariates and the interaction effects between empowerment and affective commitment, and behavior-based control and selling skills. The rationale was to examine the effects of managerial practices on adaptive behavior prior to assessing the effects of salesperson affective commitment and selling skills.

\section{Analysis and Results}

\subsection{Hypotheses Testing}

The first step in the analysis is to fit an unconditional model to test for mean differences between companies on the dependent variable (i.e. ASB). The unconditional model (the random intercept only model) was fitted first and is specified as follows:

$$
\begin{array}{lr}
(\mathrm{ASB})_{\mathrm{ij}} \quad=\beta_{0 \mathrm{j}}+\varepsilon_{\mathrm{ij}} & \text { Level 1 } \\
\beta_{0 \mathrm{j}}+\gamma_{00}+\mathrm{u}_{0 \mathrm{j}} & \text { Level 2 } \\
(\mathrm{ASB})_{\mathrm{ij}}=\gamma_{00}+\mathrm{u}_{0 \mathrm{j}}+\varepsilon_{\mathrm{ij}} & \text { Model 1 }
\end{array}
$$


The distribution of residuals associated with the salesperson-level observations is $e_{i j} \sim N\left(0, s^{2}\right)$ where $s^{2}$ represents residual variance. The distribution of the variance associated with company intercepts is $\mathrm{u}_{0 j} \sim \mathrm{N}\left(0, \mathrm{~s}_{\mathrm{C}}^{2}\right)$. These residuals and intercepts are all taken to be independent of each other. The results in Table 2 indicate that there is significant variability in ASB of salespeople both within companies (Wald $\mathrm{Z}=12.798, \mathrm{p}<0.001$ ) and between companies (Wald $\mathrm{Z}=3.971$, $\mathrm{p}<0.001)$. The intraclass correlation value is $p_{\mathrm{I}}=0.264$ suggesting that $26.4 \%$ of the variance in ASB occurs between companies. This means there is significant variability between companies in the average ASB of retail salespeople and the use of multilevel analysis as an analytical tool is appropriate.

The next model includes the two level-2 covariates (i.e. empowerment and behavior-based control), and it is specified as follows:

$$
\begin{array}{lr}
(\mathrm{ASB})_{\mathrm{ij}}=\beta_{0 \mathrm{j}}+\varepsilon_{\mathrm{ij}} & \text { Level 1 } \\
\beta_{0 \mathrm{j}}=\gamma_{00}+\gamma_{01}(\mathrm{EM})_{\mathrm{j}}+\gamma_{02}(\mathrm{BC})_{\mathrm{j}}+\mathrm{u}_{0 \mathrm{j}} & \text { Level } 2 \\
(\mathrm{ASB})_{\mathrm{ij}}=\gamma_{00}+\gamma_{01}(\mathrm{EM})_{\mathrm{j}}+\gamma_{02}(\mathrm{BC})_{\mathrm{j}}+\mathrm{u}_{0 \mathrm{j}}+\varepsilon_{\mathrm{ij}} & \text { Model } 2
\end{array}
$$

Comparing the deviance of the null model (Model 1) and the deviance of this model (Model 2) (2351.739 - 2340.975) there is a reduction of 10.8. This difference has been assessed using the chi-square distribution with 2 degrees of freedom: $\chi^{2}(2)=10.764$ with $p<0.01$ - suggesting that Model 2 fits the data better than the null model (Model 1). The results in Table 3 indicate that the coefficients for the two level-2 covariates are negative with empowerment being the only significant predictor $\left(\gamma_{01}=-1.683, \mathrm{p}<0.05\right)$. 
Insert Table 3 here

Given that Model 2 fits the data better than Model 1, we retain the main effects of level-2 covariates and proceed with the inclusion of two level-1 covariates (affective commitment and selling skills) and the two cross-level interactions: empowerment and affective commitment (EM*AC) and behavior-based control and selling skills (BBC*SS). The next model is specified as follows:

$$
\begin{array}{lr}
(\mathrm{ASB})_{\mathrm{ij}}=\beta_{0 \mathrm{j}}+\beta_{1 \mathrm{j}}(\mathrm{AC})_{\mathrm{ij}}+\beta_{2 \mathrm{j}}(\mathrm{SS})_{\mathrm{ij}}+\varepsilon_{\mathrm{ij}} & \text { Level } 1 \\
\beta_{0 \mathrm{j}}=\gamma_{00}+\gamma_{01}(\mathrm{EM})_{\mathrm{j}}+\gamma_{02}(\mathrm{BC})_{\mathrm{j}}+\mathrm{u}_{0 \mathrm{j}} ; \quad \beta_{1 \mathrm{j}}=\gamma_{10}+\gamma_{11}(\mathrm{EM})_{\mathrm{j}} ; \beta_{2 \mathrm{j}}=\gamma_{20}+\gamma_{21}(\mathrm{BC})_{\mathrm{j}} & \text { Level } 2 \\
\quad(\mathrm{ASB})_{\mathrm{ij}}=\gamma_{00}+\gamma_{10}(\mathrm{AC})_{\mathrm{ij}}+\gamma_{20}(\mathrm{SS})_{\mathrm{ij}}+\gamma_{01}(\mathrm{EM})_{\mathrm{j}}+\gamma_{02}(\mathrm{BC})_{\mathrm{j}}+\gamma_{11}(\mathrm{EM})_{\mathrm{j}} *(\mathrm{AC})_{\mathrm{ij}} & \text { Model } 3
\end{array}
$$

A comparison of the deviance of Model 2 and Model 3 (2340.975 - 1987.104) indicates that there is a reduction of 353.871. This difference, assessed using the chi-square distribution with 4 degrees of freedom suggests that Model 3 fits the data better than Model 2. The assumption of residual normality underlying Model 3 was checked using a histogram and normal Q-Q plots. These show no significant deviation from normality. Checks between the conditional predicted values and the actual observed scores of adaptive selling behavior also show a good agreement.

\subsection{Results}


The findings we present here are based on the results of Model 3. The first hypothesis $\left(\mathrm{H}_{1}\right)$ which suggests that empowerment positively influences the ASB of salespeople is not supported. More surprisingly the effect is opposite to what was expected $\left(\widetilde{I}_{01}=-0.218, \mathrm{p}>0.05\right)$. There is directional support for the second hypothesis $\left(\mathrm{H}_{2}\right)$ which indicates that behavior-based control negatively affects the practice of ASB ( $\left.\tilde{7}_{02}=-0.235, \mathrm{p}>0.05\right)$. However, the coefficient is nonsignificant and so the hypothesis is not supported.

The results indicate that affective affective commitment has a particularly strong influence on ASB ( $\left.\tilde{\vartheta}_{10}=0.308, \mathrm{p}<0.001\right)$, lending support to the third hypothesis $\left(\mathrm{H}_{3}\right)$. As expected, ASB is influenced by selling skills $\left(\hat{\gamma}_{20}=0.379, \mathrm{p}<0.001\right)$; also lending support to the fourth hypothesis $\left(\mathrm{H}_{4}\right)$. The fifth hypothesis $\left(\mathrm{H}_{5}\right)$ suggests that the effect of affective commitment on ASB is stronger for higher levels of empowerment. A positive interaction term was therefore expected. However, the results obtained do not provide support for this hypothesis ( $\tilde{1}_{11}=-0.159, \mathrm{p}>0.05$ ). The sixth hypotheses $\left(\mathrm{H}_{6}\right)$, suggesting that behavior-based control diminishes the positive effect of selling skills on adaptive selling is also not supported as the coefficient, whilst significant, is in the opposite direction to that expected $\left(\hat{\mathfrak{q}}_{12}=0.539, \mathrm{p}<0.05\right)$. In the following section, a more detailed discussion of these findings is presented.

\section{Discussion}

Our analysis, using a multilevel modeling approach for studying hierarchical (nested) data (i.e. selling skills and affective commitment at the salesperson level and empowerment and behavior-based control at sales manager level on the ASB of retail salespeople), allows responses 
at these two levels to be modeled whilst accounting for the dependencies among observations (Heck and Thomas, 2009). The results show that the two salesperson factors investigated in this study are direct determinants of adaptive selling behavior while the two contextual variables investigated do not have a direct impact on the ASB of retail salespeople. Essentially, salesperson variables play a direct role in stimulating the practice of adaptive selling in retail selling, whilst contextual variables moderate the impact of these salesperson variables.

The selling skills and affective commitment of retail sales people directly impact on their ASB. It was expected that selling skills would account for a large proportion of variance in sales performance since they are fundamental to any sales interaction. The results support this notion that selling skills significantly affects the practice of ASB and confirms findings in the literature with regards to the relationship between selling skills and salesperson performance (Churchill et al., 1985; Rentz et al., 2002). For instance, higher performing salespeople have been found to possess more distinctive sales techniques and consider more contingencies in different situations than salespeople who do not perform as well (Leong, Busch and Roedder, 1989).

The effects of organizational commitment on important work outcomes, (e.g. effort, turnover, and propensity to leave) are well established in the literature (Lee and Mathur, 1998; Naumann, Widmier and Jackson, 2000; Churchill et al., 1985). The findings presented in this study reveal that affective commitment also influences the ASB of retail salespeople. The practice of adaptive selling can thus be significantly enhanced by fostering affective organizational commitment of salespeople. 
The direct relationship between empowerment and adaptive selling is non-significant and, furthermore, is opposite to what was hypothesized. However, analogous findings have been reported in the sales literature. For instance, Rapp et al. (2006), found a negative relationship between salesperson empowerment and their working hard behaviors, as opposed to working smart behaviors. The non-significant effect of empowerment found here could possibly be attributed to many reasons. For instance, retail customers do not usually engage in negotiations, and hence there may not be any benefits to be realized through salesperson empowerment. Furthermore, salespeople are under the direct supervision of, and have greater access to, their managers if required. Consequently, even if empowerment is granted, this could be easily diluted and made redundant by sales managers' direct intervention in a sales interaction. There is also a possibility that the results could be explained by the potential moderating impact of experience on the empowerment-adaptive selling relationship. In essence, it is possible that more experienced employees do not need much empowerment to perform adaptively as they might be more aware of how to creatively adapt their behavior to sell to customers. On the other hand, less experienced employees might be less able and less willing to adapt their selling strategies unless they are empowered.

The relationship between behavior-based control and adaptive selling received weak directional support. However, the result was also non-significant. Therefore, despite the existing theoretical grounds that justified the expected impact of a behavior-based control system, the findings in this study indicate that behavior-based control does not directly influence ASB in a retail sales context. Whilst previous studies have noted this lack of a direct effect, we contended that in the retail setting (as opposed to the field sales setting) a direct effect was more likely to 
exist. However, the results indicate that even in a retail sales environment, there is no direct effect of behavior-based control on sales performance, supporting the assertion of Challagalla and Shervani (1996).

Overall, therefore we received no support for the hypothesised direct effects of the managerial constructs on the practice of adaptive selling. However, the results of both moderator hypotheses are note-worthy. We find that empowerment (contrary to what was suggested) exerts a negative moderating influence on the effect of affective commitment, whilst behavior-based control (again contrary to what was proposed) exerts a positive moderating influence on the effect of selling skills. For the moderating effect of empowerment on the link between affective commitment and adaptive selling behavior, the results suggest that as empowerment increases, the impact of affective commitment on adaptive selling diminishes. Despite this finding being contrary to what was expected, similar contra-intuitive findings regarding the role of empowerment for salespeople have been reported in previous studies. For example, in a study examining the role of employee readiness and its impact on the influence of empowerment, the findings, contrary to a hypothesis stating that individuals who are more ready (i.e. those with higher levels of job knowledge and experience) would be better suited to be empowered by a sales manager than less ready salespeople, indicated that empowerment has a greater effect on employees with less knowledge and experience (Ahearne et al., 2005). A possible explanation for our findings is that empowerment increases feelings of role ambiguity and this role ambiguity consequently diminishes the effect of affective commitment on adaptive selling. While this explanation seems plausible, there could be other explanations which suggest that the relationship between empowerment and ASB warrants further research. 
This study also reveals that behavior-based control moderates the impact of selling skills on adaptive selling. This result is interesting because, although the direct effect of behavior-based control is negative (though non-significant), it seems that behavior-based control does not weaken the effect of selling skills on adaptive selling but rather strengthens it. The inference from this is that retail salespeople depend heavily on their managers for guidance and direction and that more behavior control facilitates the practice of adaptive selling in a retail sales environment.

We suggest a plausible explanation for the moderating effect of behavior-based control: low levels of behavior-based control may suggest to salespeople that managers are not sufficiently involved in and supportive of, their work (Evans et al., 2007) and as such any ASB performed by them could go unnoticed and unrecognised. As such, salespeople may see little need to fully utilise their selling skills for adaptive selling. Retail salespeople typically draw a large part (or all) of their compensation from a fixed salary; and unlike with salespeople in the field setting, sales are not always as easily attributable to the effort of the individual retail salesperson. Therefore, retail salespeople may be less willing to use their selling skills for ASB when behavior-based control is weak. However, when managers are more involved through behaviorbased control salespeople are likely to see this as an indication that their work is important and their efforts are more likely to at least be recognised and acknowledged. Accordingly, salespeople may be more willing to put their selling skills to use by increasing their ASB when behavioral monitoring is higher. 


\subsection{Managerial Implications}

Due to the relatively mixed results of this study, it is important not to generalise the findings of this study. Rather, it is more appropriate to offer some preliminary insights into how managers might utilise this information to develop their salespeople and create a more adaptive sales force.

When considering the factors that influence the ASB of retail salespeople, the results of this study indicate that selling skills and affective commitment have the strongest direct influence. We suggest that managers of retail sales organizations should consider how their policies and the structure of the work itself can be adjusted or altered to increase salespersons’ affective commitment. This necessitates ensuring there is congruence between the values and goals of their salespeople and those of the organization. However, commitment must be reciprocal. For instance, if salespeople are concerned about losing their jobs, there is very little chance that they will be willing to exert considerable effort in their job. To this end, aspects of management styles (e.g., degree of management emphasis on flexibility and adaptation perceived by employees) that have been found to have a significant consequences for employee commitment (Zeffane, 1994) may be used to enhance affective commitment and thus increase the practice of ASB among retail salespeople.

Furthermore, employing salespeople with strong sales skills and providing them opportunities to improve their skills will have a positive impact on their ASB. In order to improve selling skills, managers should focus on training employees. An effective approach is to have better skilled salespeople train less skilled salespeople, particularly on how to recognise customer needs and consequently about the selling strategies to adopt for satisfying those needs. 
Based on the results of this study, empowering retail salespeople does not improve ASB. The increased capability to exercise judgment and instigate initiatives is of no real benefit to retail salespeople. Retail salespeople are salaried employees, and therefore are hindered rather than motivated to practice ASB by empowerment. Consequently, sales managers interested in using empowerment to increase the practice of ASB by their salespeople must carefully consider the necessary conditions under which such an initiative could produce the desired outcome or be detrimental to sales performance.

Finally, according to the results, it is apparent that managers should be mindful of the interaction between selling skills and control systems in influencing salesperson ASB. Salespeople are more likely to utilize their selling skills for adaptive selling when behaviorcontrol is strong than when it is weak. Managers must therefore be seen by salespeople to be close enough to the sales encounter through behavior-based control in order to enhance the practice of ASB among their salesforce.

\subsection{Limitations and Future Research Directions}

Whilst our study contributes to the sales literature, and, we hope, is the foundation for additional work, we acknowledge that it is not perfect. The first limitation is that our study is limited to the context of the Greek retail sector and as such the findings cannot be uncritically generalized to retail contexts in other national and cultural environments. Secondly, our study was conducted in the context of small retail outlets. In such outlets, sales managers and salespeople are in closer contact than in larger outlets where contact could be more limited. As 
such, our study's findings are somewhat limited to small retail sales outlets. Thirdly, only a limited number of sub-dimensions of some of the predictor variables are used; for instance, normative and continuance commitment, have not been examined. In addition, although the scales have been subjected to back translation and a rigorous pre-testing process, conceptual equivalence has not been formally assessed.

In terms of future research, it has been suggested that the global construct of behavior-based control is insufficiently discriminatory and that it is useful to distinguish between activity and capability control (Challagalla and Shervani, 1996). This distinction has not been made in this study but may be useful to explore in future studies. Furthermore, since we did not find a direct effect of behavior-based control on adaptive selling, it might also be useful to test for mediating variables that might link behavior-based control to adaptive selling.

Given our results in relation to the role of empowerment, we suggest that further research is essential in this area. In this study, empowerment has been assessed by sales managers, and not salespeople. A critical question in this regard is whether or not sales people in these organizations felt as empowered as sales managers thought they were. Future studies will benefit from assessing empowerment from an employee perspective in addition to establishing congruence relations between manager and salesperson perceptions of empowerment. Research that specifically takes into account contextual factors in different retail sales environments might also be needed to shed more light on the role of empowerment for retail salespeople. Future research might additionally consider other salesperson characteristics such as power motivation and need for recognition as possible moderators of the influence of empowerment on adaptive 
selling. Furthermore, given the relationship between selling skills and ASB, a promising area of further research is the investigation of more boundary conditions such as motivation and role clarity on the influence of selling skills on adaptive selling. 


\section{References}

Ahearne M, Mathieu J, Rapp A. To empower or not to empower your sales force? An empirical examination of the influence of leadership empowerment behavior on customer satisfaction and performance. Journal of Applied Psychology 2005; 90(5):945-955.

Ahearne M, Rapp A, Hughes DE, Jindal R. Managing sales force product perceptions and control systems in the success of new product introduction. Journal of Marketing Research 2010; 47:764-776.

Anderson RE, Huang WR. Empowering salespeople: personal, managerial, and organizational perspectives. Psychology and Marketing 2006; 23(2):139-159.

Anderson E, Oliver RL. Perspectives on behavior-based versus outcome based salesforce control systems. Journal of Marketing, 1987; 51:76-88.

Arnold JJ, Arad S, Rhoades JA, Drasgow F. The empowering leadership questionnaire: the construction and validation of a new scale for measuring leader behaviors. Journal of Organizational Behavior 2000;21(3):249-269.

Arnold TJ, Palmatier RW, Grewal D, Sharma A. Understanding retail managers’ role in the sales of products and services. Journal of Retailing 2009;85(2):129-144.

Babakus E, Cravens DW, Grant K., Ingram TN, LaForge RW. Investigating the relationships among sales management control, sales territory design, salesperson performance, and sales organization effectiveness. International Journal of Research in Marketing 1996;13: 345-363.

Bandura A. Social foundations of thought and action: A social-cognitive view. Englewood Cliffs, NJ: Prentice-Hall; 1986 
Barry J, Weinstein A. Business psychographics revisited: from segmentation theory to successful marketing practice. Journal of Marketing Management 2009;25(3-4):315-340.

Behrman DN, Perreault WD. Measuring the performance of individual salespersons. Journal of Business Research 1982;10:335-370.

Bodkin CD, Stevenson TH. Adaptive behavior in selling: a discriminant analysis of the effect of situational variables. Journal of Marketing Management 1993;3(2):25-35.

Bodkin CD, Stevenson TH. Antecedents of salesperson adaptive behavior: the effects of relational, self-consciousness, and experiential variables. Journal of Marketing Management 1996;5(1):61-78.

Boorom ML, Goolsby JR, Ramsey RP. Relational communication traits and their effect on adaptiveness and sales performance. Journal of the Academy of Marketing Science, 1998; 26:16-30.

Brown SP, Peterson RA. Antecedents and consequences of salesperson job satisfaction: metaanalysis and assessment of causal effects. Journal of Marketing Research 1993;30(1):6377.

Burke W. Leadership as empowering others. In S. Srivastra, Editor. Executive power. San Francisco: Jossey-Bass; 1986. p. 51-77

Bush RP, Bush AJ, Ortinau DJ, Hair Jr. JF. Developing a behavior-based scale to assess retail salesperson performance. Journal of Retailing 1990;66:119-136.

Cannon JP, Perreault Jr. WD. Buyer-seller relationships in business markets. Journal of Marketing Research 1999;3:439-460.

Challagalla GN, Shervani TA. Dimensions and types of supervisory control: effects on salesperson performance and satisfaction. Journal of Marketing 1996;60:89-105. 
Chonko LB. Organizational commitment in the sales force. Journal of Personal Selling and Sales Management 1986;6:19-27.

Churchill GA Jr., Ford NM, Walker OC Jr. Sales force management. Homewood, IL: Irwin; 1997.

Churchill GA Jr., Ford NM, Hartley SW, Walker OC Jr. The determinants of salesperson performance: a meta-analysis. Journal of Marketing Research, 1985;22(2):103-118.

Cohen A. On the discriminant validity of the Meyer and Allen measure of organizational commitment: how does it fit with the work commitment construct. Educational and Psychological Measurement 1996;56(3):494-593.

Conger JA, Kanungo RN. The empowerment process: integrating theory and practice. The Academy of Management Review 1988:13(3):471-482.

Cook JD, Hepworth SJ, Wall TD, Warr PB. The experience of work. New York: Academic Press; 1981.

Cravens DW, Lassk FG, Low GS, Marshall GW, Moncrief WC. Formal and informal management control combinations in sales organizations: The impact on salesperson consequences. Journal of Business Research 2004;57:241-248.

Deci EL. Intrinsic motivation. New York: Plenum; 1975.

Eckert JA. Adaptive selling behavior: adding depth and specificity to the range of adaptive outputs. American Journal of Business 2006;21(1):31-39.

Evans KR, Landry TD, Li PC, Zou S. How sales controls affect job-related outcomes: the role of organizational sales-related psychological climate perceptions. Journal of the Academy of Marketing Science 2007;35(3):445-459. 
Gengler CE, Howard DJ, Zolner K. A personal construct analysis of adaptive selling and sales experience. Psychology and Marketing 1995;12(4):287-304.

Giacobbe RW, Jackson DW Jr., Crosby LA, Bridges CM. A contingency approach to adaptive selling behavior and sales performance: selling situations and salesperson characteristics. Journal of Personal Selling and Sales Management 2006;26(2):115-142.

Goff BG, Bellenger DN, Stojack C. Cues to consumer susceptibility to salesperson influence: Implications for adaptive retail selling. Journal of Personal Selling and Sales Management 1994;14(2):25-39.

Goolsby JR, Lagace RR, Boorom ML. Psychological adaptiveness and sales performance. Journal of Personal Selling and Sales Management 1992;12(2):51-66.

Fang E, Evans KR, Zou S. The moderating effect of goal-setting characteristics on the sales control systems-job performance relationship. Journal of Business Research 2005;58:1214-1222.

Foster C, Whysall P, Harris L. Employee loyalty: an exploration of staff commitment levels towards retailing, the retailer and the store. The International Review of Retail, Distribution and Consumer Research, 2008;18(4):423-435.

Franke GR, Park JE. Salesperson adaptive selling behavior and customer orientation: a metaanalysis. Journal of Marketing Research 2006;43(4):693-702.

Fu FQ, Bolander W, Jones E. Managing the drivers of organizational commitment and salesperson effort: an application of Meyer and Allen’s three-component model. Journal of Marketing Theory and Practice 2009;17(4):335-350.

Hartline MD, Ferrell OC. The management of customer-contact service employees: an empirical investigation. Journal of Marketing 1996;60:52-70. 
Heck RH, Thomas SL. An introduction to multilevel modeling techniques. Routledge; 2009.

Hunt SD, Chonko LB, Wood VR. Organizational commitment and marketing. Journal of Marketing 1985;49(1):112-126.

Jaramillo F, Mulki JP, Marshall GW. A meta-analysis of the relationship between organizational commitment and salesperson job performance: 25 years of research. Journal of Business Research 2005;58:705-714.

Jaworski BJ, Stathakopoulos V, Krishnam HS. Control considerations in marketing: conceptual framework and empirical evidence. Journal of Marketing 1993;57:57-69.

Jaworski BJ, MacInnis D. Marketing jobs and management controls: toward a framework. Journal of Marketing Research 1989;26:406-419.

Johnston MW, Parasuraman A, Futrell CM, Black WC. A longitudinal assessment of the impact of selected organizational influences on salespeople’s organizational commitment during early employment. Journal of Marketing Research 1990;27:333-344.

Ingram TN, Lee KS, Skinner SJ. An empirical assessment of salesperson motivation, commitment, and job outcomes. Journal of Personal Selling and Sales Management, 1989;9:25-34.

Leach DJ, Wall TD, Jackson PR. The effect of empowerment on job knowledge: an empirical test involving operators of complex technology. Journal of Occupational and Organizational Psychology 2003;76:27-52.

Lee KS, Mathur A. Formalization, role stress, commitment, and work outcomes: an empirical analysis of South Korean workers. Journal of Asia-Pacific Business, 2199;8(3):45-64.

Leong SM, Busch PS, Roedder JD. Knowledge bases and salesperson effectiveness: a scripttheoretic analysis. Journal of Marketing Research 1989;26:164-178. 
Levy M, Sharma A. Adaptive selling: the role of gender, age, sales experience, and education. Journal of Business Research 1994;31(1):39-47.

Lusch RF, Jaworski BJ. Management controls, role stress, and retail store manager performance. Journal of Retailing 1991;67(4):397-419.

Mallalieu L. Adaptive selling behavior among retail salespeople: the use of overt cues and consumer stereotypes. Advances in Consumer Research 2006; 34:409-410.

Mallin ML, Pullins EB. The moderating effect of control systems on the relationship between commission and salesperson intrinsic motivation in a customer oriented environment. Industrial Marketing Management 2009;38(7):769-777.

Meyer JP, Allen NJ. Commitment in the workplace. Sage Publications: Thousand Oaks, CA; 1997.

Meyer JP, Stanley DJ, Herscovitch L, Topolnytsky L. Affective, continuance, and normative commitment to the organization: a meta-analysis of antecedents, correlates, and consequences. Journal of Vocational Behavior 2002;61:20-52.

Michaels RE, Cron WL, Dubinsky AJ, Joachimsthaler EA. Influence of formalization on the organizational commitment and work alienation of salespeople and industrial buyers. Journal of Marketing Research 1988;25(4):376-383.

Mowday RT, Steers RM, Porter LW. The measure of organizational commitment. Journal of Vocational Behavior 1979;14(2):224-247.

Naumann E, Widmier SM, Jackson DW Jr. Examining the relationship between work attitudes and propensity to leave among expatriate salespeople. Journal of Personal Selling and Sales Management 2000;20:227-241. 
Oliver RL, Anderson E. An empirical test of the consequences of behavior and outcome-based sales control systems. Journal of Marketing 1994;58:53-67.

Park JE, Holloway BB. Adaptive selling behavior revisited: an empirical examination of learning orientation, sales performance, and job satisfaction. Journal of Personal Selling and Sales Management 2003;23(3):239-251.

Pettijohn EC, Pettijohn S, Taylor AJ, Keillor DB. Adaptive selling and sales performance: an empirical examination. The Journal of Applied Business Research 2000;16(1):91-111.

Pettijohn CE, Pettijohn LS, Taylor AJ. Does salesperson perception of the importance of sales skills improve sales performance, customer orientation, job satisfaction, and organizational commitment, and reduce turnover? Journal of Personal Selling and Sales Management 2007;27(1):75-88.

Piercy NF, Cravens DW, Morgan NA. Salesforce performance and behavior-based management processes in business-to business sales organizations. European Journal of Marketing 1998;32(1/2):79-100.

Plouffe CR, Hulland J, Wachner T. Customer-directed selling behaviors and performance: a comparison of existing perspectives. Journal of the Academy of Marketing Science 2009;37(4):422-439.

Porter SS, Wiener JL, Frankwick GL. The moderating effect of selling situation on the adaptive selling strategy-selling effectiveness relationship. Journal of Business Research 2003;56:275-281.

Ramaswami SN. Marketing control and dysfunctional employee behaviors: a test of traditional and contingency theory postulates. Journal of Marketing 1996;60:105-20. 
Rapp A, Ahearne M, Mathieu J, Schillewaert N. The impact of knowledge and empowerment on working smart and working hard: The moderating role of experience. International Journal of Research in Marketing 2006;23:279-293.

Rent JO, Shepherd C.D, Tashchian A, Dabholkar PA, Ladd RT. A measure of selling skill: scale development and validation. Journal of Personal Selling and Sales Management 2002;22(1):13-21.

Robinson L Jr., Marshall GW, Moncrief WC, Lasek FG. Toward a shortened measure of adaptive selling. Journal of Personal Selling and Sales Management 2002;22(2):111-119.

Román S, Iacobucci D. Antecedents and consequences of adaptive selling confidence and behavior: a dyadic analysis of salespeople and their customers. Journal of the Academy of Marketing Science 2010;38:363-382.

Scott S, Bruce R. Determinants of innovative behavior: a path model of individual innovation in the workplace. Academy of Management Journal 1994;37(3):580-628.

Singh J, Verbeke W, Rhoads GK. Do organizational practices matter in role stress processes? a study of direct and moderating effects for market-oriented boundary spanners. Journal of Marketing 1996;60(3):69-76.

Sharma A, Levy M. Categorization of customers by retail salespeople. Journal of Retailing, 1995;71(1):71-81.

Sharma A, Levy M, Kumar A. Knowledge structures and retail sales performance: an empirical examination. Journal of Retailing 2000;76(1):53-69.

Sharma A. Consumer decision-making, salespeople’s adaptive selling and retail performance. Journal of Business Research 2001;54:125-129. 
Siguaw J. An examination of adaptive selling antecedents and outcomes. In Levy M, Grewal D, editors. 1993 Annual Conference of the Academy of Marketing Science Proceedings, vol. 16. Miami: Academy of Marketing Science, 1993. p. 295

Snijders TAB, Bosker RJ. Multilevel analysis: An introduction to basic and advanced multilevel modeling. Sage Publications; 2004.

Spiro RL, Weitz BA. Adaptive selling: conceptualization, measurement, and nomological validity. Journal of Marketing Research 1990;27(1):61-69.

Stewart A. A realistic look at organizational loyalty. Management Review 1961;19(1):100-105.

Still LV. Part-time versus full-time salespeople: individual attributes, organizational commitment, and work attitudes. Journal of Retailing 1983;59(2):55-79.

Sturges J, Guest D, Conway N, Mackenzie-Davey K. What difference does it make? a longitudinal study of the relationship between career management and organizational commitment in the early years of work. Academy of Management Proceedings, B1-B6. Academy of Management, 2001.

Sujan H, Weitz BA, Sujan M. Increasing sales productivity by getting salespeople to work smarter. Journal of Personal Selling and Sales Management 1988;8:9-19.

Sujan H, Weitz B, Kumar N. Learning orientation, working smart and effective selling. Journal of Marketing, 1994; 3: 39-52.

Swailes S. Organizational commitment: a critique of the construct and measures. International Journal of Management Reviews 2002;4(2):155-178.

Thomas KW, Velthouse BA. Cognitive elements of empowerment: an interpretive model of intrinsic task motivation. Academy of Management Review 1990;15:666-681. 
Wachner T, Plouffe CR, Grégoire Y. SOCO’s impact on individual sales performance: the integration of selling skills as a missing link. Industrial Marketing Management, 2009;38(1):32-44.

Walker OC Jr., Churchill GA Jr., Ford NM. Motivation and performance in industrial selling: present knowledge and needed research. Journal of Marketing Research 1977;14(2):156168.

Weitz BA. Relationship between salesperson performance and understanding of customer decision making. Journal of Marketing Research 1978;15(4):501-516.

Weitz BA, Sujan H, Sujan M. Knowledge, motivation, and adaptive behavior: a framework for improving selling effectiveness. Journal of Marketing 1986;50:174-191.

Verbeke W, Belschak F, Bagozzi RP. The adaptive consequences of pride in personal selling. Journal of the Academy of Marketing Science 2004;32(4):386-402.

Zeffane R. Patterns of organizational commitment and perceived management style: a comparison of public and private sector employees. Human Relations 1994;47:977-1010.

Zeithaml VA, Parasuraman A, Berry LL. Delivering quality service. Free Press: New York; 1990. 


\section{Appendix: Measurement Scales}

- Sales Managers

$\underline{\text { Empowerment }}$

EM 1 I allow employees complete freedom in their work.

EM 2 I permit employees to use their own judgment in solving problems.

EM 3 I encourage initiative in my employees.

EM 4 I let employees do their work the way they think best.

EM 5 I assign tasks, then let employees handle them.

EM 6 I turn employees loose on a job, and let them go to it.

EM 7 I allow employees a high degree of initiative.

EM 8 I trust employees to exercise good judgment.

Sources: Cook JD, Hepworth SJ, Wall TD, Warr PB. The experience of work. New York: Academic

Press; 1981; Hartline MD, Ferrell OC. The management of customer-contact service employees: an empirical investigation. Journal of Marketing 1996;60:52-70.

\section{Behavior Based Control}

BC 1 A track record of courteous service to customers.

BC 2 The ability to resolve customer complaints or service problems in an efficient manner.

BC 3 The ability to innovatively deal with unique situations and /or meet customer needs.

BC 4 The employee's commitment to the organization.

BC 5 The employee's commitment to customers. 
Source: Bush RP, Bush AJ, Ortinau DJ, Hair JF Jr. Developing a behavior-based scale to assess retail salesperson performance. Journal of Retailing 1990;66:119-136.

- Salespeople

$\underline{\text { Adaptive Selling Behavior }}$

AD 1 When I feel that my approach is not working, I can easily change to another approach.

AD 2 I like to experiment with different approaches.

AD 3 I am very flexible in the selling approach that I use.

AD 4 I can easily use a wide variety of selling approaches.

AD 5 I try to understand how one customer differs from another.

Source: Robinson L Jr., Marshall GW, Moncrief WC, Lasek FG. Toward a shortened measure of adaptive selling. Journal of Personal Selling and Sales Management 2002;22(2):111-119.

\section{Affective Organizational Commitment}

AC 1 I am willing to put in a great deal of effort beyond that normally expected to help this organization be successful.

AC 2 I talk about this organization to my friends as a great place to work.

AC 3 I would accept almost any type of job assignment in order to keep working for this organization.

AC 4 I find that my values and the organization's values are similar.

AC 5 I am proud to tell others that I am part of this organization. 
AC 6 This organization really inspires the very best in me in the way of job performance.

AC 7 I am extremely glad that I chose this organization to work for over others I was considering at the time I joined.

AC 8 I really care about the fate of this organization.

AC 9 For me, this is the best of all possible organizations for which to work.

Source: Mowday RT, Steers RM, Porter LW. The measurement of organizational commitment. Journal of Vocational Behavior 1979;14:224-247.

\section{Selling Skills}

SS 1 I listen attentively to identify and understand the real concerns of customers.

SS 2 I make sure that what customers demand is what they actually need.

SS 3 Working out solutions to customers' questions and objectives.

Source: Behrman DN, Perreault WD. Measuring the performance of individual salespersons. Journal of Business Research 1982;10:335-370 (Reduced from 5 to 3 items prior to its use - also SS2 was slightly modified). 


\section{Figure 1: Hypothesized Relationships}

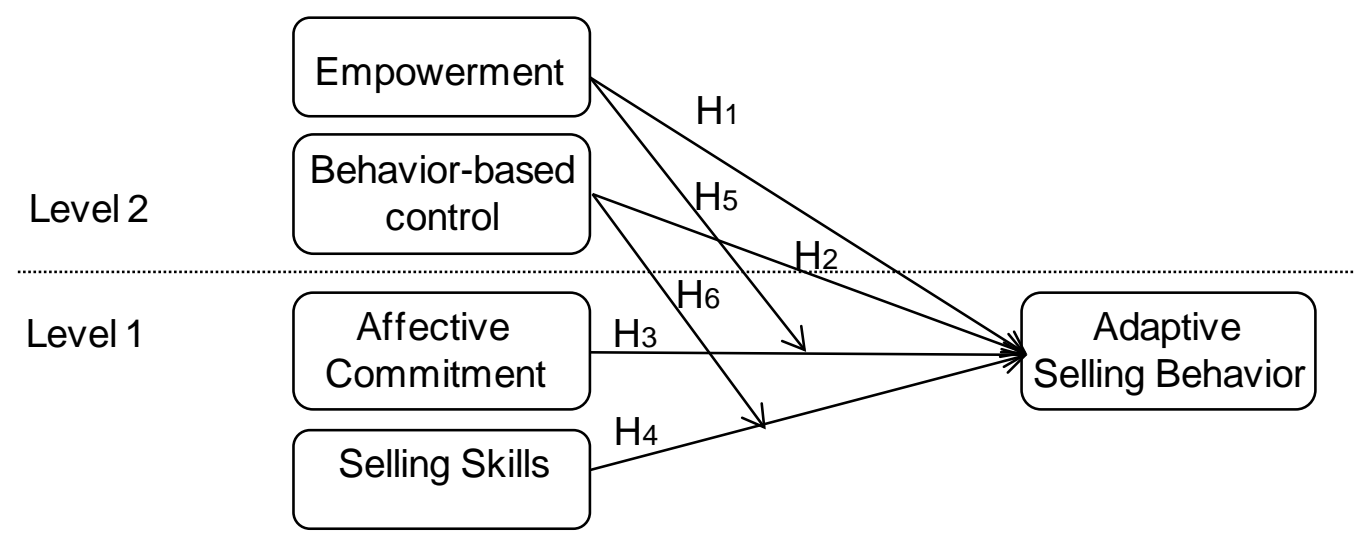

Table 1: A summary of variables used in the multi-level analysis

\begin{tabular}{|c|c|c|c|}
\hline \multicolumn{2}{|c|}{ Manager-level (Level 2) } & \multicolumn{2}{c|}{ Salesperson-level (Level 1) } \\
\hline Subject ID & Covariates & Covariates & Dependent Variable \\
\hline $\begin{array}{c}\text { Company } \\
\text { ID }\end{array}$ & $\begin{array}{c}\text { Empowerment (EM) } \\
\text { Behavioral Control (BC) }\end{array}$ & $\begin{array}{c}\text { Affective Commitment } \\
\text { (AC) } \\
\text { Selling Skills (SS) }\end{array}$ & $\begin{array}{c}\text { Adaptive Selling Behavior } \\
\text { (ASB) }\end{array}$ \\
\hline
\end{tabular}


Table 2: Means, standard deviations, and correlations among variables

\begin{tabular}{|l|l|l|c|c|c|c|c|c|c|}
\hline Variable & CR & AVE & Mean & SD & 1 & 2 & 3 & 4 & 5 \\
\hline $\begin{array}{l}\text { 1. Adaptive Selling } \\
\text { Behavior (ASB) }\end{array}$ & 0.88 & 0.61 & 5.31 & 0.85 & 1 & 0.05 & $0.14^{*}$ & $0.75^{* * *}$ & $0.68^{* * *}$ \\
\hline $\begin{array}{c}\text { 2. Empowerment } \\
(E M)\end{array}$ & 0.77 & 0.51 & 5.51 & 0.93 & & 1 & $0.30^{* * *}$ & $0.14^{* *}$ & -0.03 \\
\hline $\begin{array}{c}\text { 3. Behavior-Based } \\
\text { Control (BC) }\end{array}$ & 0.83 & 0.40 & 4.35 & 0.50 & & & 1 & $.151^{* *}$ & $0.14^{* *}$ \\
\hline $\begin{array}{c}4 . \text { Affective } \\
\text { Commitment (AC) }\end{array}$ & 0.91 & 0.58 & 5.28 & 0.88 & & & & 1 & $0.68^{* * *}$ \\
\hline 5. Selling Skills (SS) & 0.84 & 0.65 & 5.44 & 0.93 & & & & & 1 \\
\hline
\end{tabular}

$\mathrm{N}=419 ;{ }^{* * *} \mathrm{p}<0.001 ;{ }^{* *} \mathrm{p}<0.005 ;{ }^{*} \mathrm{p}<0.05$.

Table 3 Parameter Estimates ${ }^{1}$ for Models Examining the Impact of Influencing Factors on ASB.

\begin{tabular}{|c|c|c|c|c|}
\hline & & $\begin{array}{l}\text { Model } 1 \\
\text { Estimate } \\
(S E)\end{array}$ & $\begin{array}{l}\text { Model } 2 \\
\text { Estimate } \\
(S E)\end{array}$ & $\begin{array}{l}\text { Model } 3 \\
\text { Estimate } \\
\text { (SE) }\end{array}$ \\
\hline \multicolumn{5}{|l|}{ Fixed Effects } \\
\hline Intercept & ${ }_{0}^{70}$ & & $\begin{array}{c}26.784 * * * \\
(.286) \\
\end{array}$ & $\begin{array}{c}26.508 * * * \\
(.154)\end{array}$ \\
\hline $\begin{array}{c}E M \\
\text { (Empowerment) }\end{array}$ & $\begin{array}{l}70 \\
1\end{array}$ & & $\begin{array}{c}-1.683^{*} \\
(.843)\end{array}$ & $\begin{array}{l}-.218 \\
(.455)\end{array}$ \\
\hline $\begin{array}{c}B C \\
\text { (Behavior-based } \\
\text { Control) }\end{array}$ & 2 & & $\begin{array}{l}-1.033 \\
(1.311)\end{array}$ & $\begin{array}{l}-.235 \\
(.722)\end{array}$ \\
\hline $\begin{array}{c}A C \\
\text { (Affective } \\
\text { Commitment) }\end{array}$ & $\mathbb{Z}^{\mathbb{1} 1}$ & & & $\begin{array}{l}.308 * * * \\
(.023)\end{array}$ \\
\hline $\begin{array}{c}S S \\
\text { (Selling Skills) }\end{array}$ & $\mathbb{7}_{2}$ & & & $\begin{array}{c}.379 * * * \\
(.066)\end{array}$ \\
\hline$E M^{*} A C$ & $\begin{array}{l}71 \\
1 \\
\end{array}$ & & & $\begin{array}{c}-.159 * * * \\
(.044)\end{array}$ \\
\hline$B C * S S$ & $7^{71}$ & & & $\begin{array}{l}.539 * \\
(.209)\end{array}$ \\
\hline \multicolumn{5}{|l|}{ Random Effects } \\
\hline Residual & $2^{s}$ & $\begin{array}{c}.13 .099 * * \\
* \\
(1.024)\end{array}$ & $\begin{array}{c}13.081 * * * \\
(1.018)\end{array}$ & $\begin{array}{c}6.028 * * * \\
(.466)\end{array}$ \\
\hline Company intercept & $s$ & $4.706 * * *$ & $4.319 * * *$ & $.660 *$ \\
\hline
\end{tabular}

\footnotetext{
${ }^{1}$ All estimates and standard errors are rounded to the last digit.
} 


\begin{tabular}{|c|c|c|c|c|}
\hline & ${ }^{2} \mathrm{C}$ & $\mathbf{( 1 . 1 8 5 )}$ & $\mathbf{( 1 . 1 1 8 )}$ & $(.314)$ \\
\hline Deviance (-2LL) & & 2351.7 & 2340.9 & 1987.1 \\
\hline
\end{tabular}

${ }^{*} p<.05 ;{ }^{* *} p<.01 ; * * * p<.001$ 